\title{
VARIASI METODE DALAM PEMBELAJARAN MEMBACA DI PROGRAM STUDI BAHASA JEPANG DI SEKOLAH VOKASI UGM
}

\author{
Wahyu Handayani Setyaningsih \\ Prodi Bahasa Jepang Sekolah Vokasi Universitas Gadjah Mada \\ Email:wahyuhs2015@gmail.com
}

\begin{abstract}
:
Learning method is one of the important aspects to reach the aim of learning. In foreign language learning, especially in Japanese, various method is needed in order to improve the student's skill and also give chance to the students to be more active in learning Japanese. This paper aims to explore the impact of various method used in Japanese learning in Vocational College, UGM. Based on the research, there are several impact on various method use to the student's learning outcome. First, the students become more active in learning and show their opinions. Second, various method build the student's selfreliance, and third, improving the student's skill of communication, especially in Japanese.
\end{abstract}

Key words: learning method, reading, Japanese

Intisari:

Metode pembelajaran merupakan salah satu aspek penting dalam tercapainya suatu tujuan pembelajaran. Dalam pembelajaran bahasa asing, khususnya Bahasa Jepang, diperlukan adanya variasi metode agar mahasiswa lebih aktif dalam belajar dan mampu meningkatkan hasil belajar. Tulisan ini melihat pengaruh penggunaan beberapa metode belajar terhadap hasil belajar mahasiswa dalam mata kuliah Membaca pada Program Studi Bahasa Jepang, Sekolah Vokasi UGM. Dari hasil penelitian yang dilakukan, diketahui terdapat pengaruh dari penerapan variasi metode terhadap hasil belajar mahasiswa. Pertama, mahasiswa menjadi lebih aktif belajar dan mengemukakan pendapat. Kedua, kemandirian mahasiswa lebih terlatih, dan ketiga, kemampuan berkomunikasi mahasiswa meningkat, khususnya dalam Bahasa Jepang.

Kata kunci: metode, pembelajaran, membaca, Bahasa Jepang 


\section{Pendahuluan}

Secara umum, dalam kemampuan berbahasa terdapat empat aspek keterampilan yang harus dimiliki serta dikuasai oleh pembelajar bahasa. Empat keterampilan tersebut adalah keterampilan mendengarkan, berbicara, membaca, dan menulis. Empat keterampilan ini menjadi dasar bagi pembuatan kurikulum pendidikan bahasa di Indonesia. Bahasa Jepang merupakan salah satu bahasa asing yang dianggap sulit karena selain menggunakan huruf Kanji, juga memiliki struktur tata bahasa yang berbeda dengan bahasa lainnya. Dalam sebuah artikel yang dimuat dalam website NSA pada bulan Mei 2016 Ialu, disebutkan bahwa Bahasa Jepang memiliki tingkat kesulitan tertinggi dibandingkan bahasa asing lainnya.

".... Give a set of totally unfamiliar words in various languages to students who know little of a language except how to look up words in a dictionary. Students of Spanish, French, German, or any other alphabetical language, will finish their task much more quickly than students of Chinese, Japanese, or Korean. We can conclude that Japanese has the most difficult writing system among those languages which use non-Latin
Alphabets. In addition to 94 Hiragana, Katakana, and auxiliary symbols, Japanese has Chinese characters each of which has more than one reading. Next is Korean, which has Hangul in addition to Chinese characters. The Chinese writing system is third, followed by the Arabic system, which has 100 symbols, and Hebrew with 28 symbols."

Dari tulisan tersebut diketahui bahwa Bahasa Jepang merupakan salah satu bahasa asing yang memiliki tingkat kesulitan tinggi. Salah satu komponen dalam empat keterampilan berbahasa yang seringkali dianggap sulit adalah membaca dan memahami teks bacaan. Dalam pembelajaran Bahasa Jepang, mata kuliah Membaca merupakan salah satu yang dianggap sulit oleh mahasiswa. Mata kuliah ini terintegrasi langsung dengan mata kuliah Tata Bahasa, Menulis, dan Berbicara sehingga diperlukan kemampuan ketiga mata kuliah tersebut untuk dapat memahami suatu teks bacaan. Dengan demikian, diperlukan suatu strategi belajar untuk dapat meningkatkan pemahaman mahasiswa.

Pembelajaran Membaca yang telah dilakukan selama ini lebih banyak

\footnotetext{
${ }^{1}$ https://www.nsa.gov/newsfeatures/declassified-documents/cryptologicspectrum/assets/files/foreign language.pdf.
} 
dengan metode Teacher Centered Learning ( $T C L)$. Metode ini lebih menitikberatkan dosen sebagai penyampai materi. Model pembelajaran konvensional memiliki langkah-langkah pembelajaran. Langkah-langkah pembelajaran tersebut adalah 1) apersepsi2; 2) guru atau dosen menjelaskan materi pelajaran secara utuh dan menyeluruh; 3) guru atau dosen memberikan tugas pada siswa untuk diselesaikan; dan 4) kegiatan penutup; guru atau dosen memberikan evaluasi dan memberikan tugas sebagai tindak lanjut (Suryosubroto dalam Rosdiana, 2009).

Dilihat dari langkah-langkah pembelajaran konvensional tersebut terlihat bahwa model pembelajaran konvensional memiliki beberapa kelemahan, yaitu 1) mahasiswa menjadi pasif; 2) mahasiswa mudah bosan; dan 3) pembelajaran terfokus pada buku teks

2 Apersepsi adalah pengamatan secara sadar (penghayatan) tentang segala sesuatu di jiwanya (dirinya) sendiri yang menjadi dasar perbandingan serta landasan untuk menerima ide baru (KBBI, 2003: 60). Menurut Herbart dalam Mansur (2015: 9) apersepsi adalah memperoleh tanggapantanggapan baru dengan bantuan tanggapan yang telah ada. Jadi menurut Herbart bahwa sesuatu yang telah diketahui dapat digunakan untuk memahami sesuatu yang belum diketahui. Dapat disimpulkan bahwa apersepsi adalah Jurnal Lingua Aplicata Volume 1, Nomor 1 September 2017 saja. Untuk menciptakan situasi pembelajaran yang lebih interaktif, menyenangkan, serta memotivasi mahasiswa dalam proses pembelajaran, dosen bisa memberikan kesempatan kepada mahasiswa untuk menemukan sendiri, melakukan penyelidikan, mencoba menganalisis serta berdiskusi melalui interaksi teman kelompoknya. Beberapa metode pembelajaran dapat diterapkan dalam mata kuliah Membaca.

Untuk melihat adanya pengaruh penerapan metode belajar terhadap hasil pembelajaran mahasiswa, dilakukan observasi dalam mata kuliah Membaca III di Program Studi DIII Bahasa Jepang, Sekolah Vokasi UGM. Observasi dilakukan terhadap mahasiswa dari dua angkatan, yaitu 2014 dan 2015. Observasi dilakukan dengan melihat pengaruh penerapan metode pembelajaran konvensional dan penerapan beberapa metode dalam pembelajaran.

menghubungkan pelajaran lama dengan pelajaran baru, sebagai batu loncatan sejauh mana peserta didik menguasai pelajaran lama sehingga dengan mudah menyerap pelajaran baru. Apersepsi biasanya dilakukan sebagai bagian dari pendahuluan dan berfungsi mengaitkan informasi yang telah diketahui peserta didik dengan topik bahasan yang akan dipelajari. 
Observasi pertama dilakukan pada mata kuliah Membaca III angkatan 2014. Mahasiswa dibagi menjadi dua kelas, yaitu sebagai kelas kontrol dan kelas eksperimen. Tingkat pemahaman mahasiswa dilihat melalui nilai tes yang dilakukan pada masing-masing kelas, sebelum dan sesudah diberikannya treatment. Observasi kedua dilakukan pada mahasiswa angkatan 2015 dengan memberikan treatment tambahan, yaitu metode presentasi. Pengaruh penerapan metode pembelajaran terhadap pemahaman mahasiswa dilihat melalui nilai mahasiswa dalam mata kuliah Membaca III.

\section{Metode Kooperatif Dalam}

\section{Pembelajaran Bahasa Asing}

Untuk mengatasi kelemahankelemahan yang terdapat dalam metode konvensional, maka dapat diterapkan metode pembelajaran yang melibatkan siswa secara penuh dalam proses pembelajaran. Terdapat banyak metode pembelajaran yang berpusat pada siswa (student centered learning), salah satunya adalah metode pembelajaran kooperatif (cooperative learning) (Slavin, 2008). Pembelajaran kooperatif dinilai efektif karena mahasiswa dapat belajar dalam kelompok-kelompok kecil untuk bekerjasama saling membantu dalam memahami materi pembelajaran dan mengemukakan pendapat sehingga mahasiswa termotivasi untuk belajar dengan baik yang dapat mempengaruhi peningkatan prestasi belajar (Croce, 2007; Kolawole, 2008; Slavin, 2008; Zakaria dan Iksan, 2007).

Arends (2008) menyebutkan bahwa metode pembelajaran kooperatif dikembangkan untuk mencapai tiga tujuan penting, yaitu:

1. Meningkatkan prestasi akademik mahasiswa;

2. Meningkatkan kerja sama dan toleransi antar mahasiswa;

3. Meningkatkan penerimaan mahasiswa terhadap keanekaragaman dan meningkatkan pengembangan keterampilan sosial mahasiswa. Pembelajaran kooperatif dianggap memiliki kelebihan dibandingkan dengan pembelajaran tradisional. Kelebihan tersebut adalah, 1) pembelajaran lebih terstruktur atas dasar prinsip-prinsip saling ketergantungan positif di antara mahasiswa; 2) interaksi promotif tatap muka; 3) tanggung jawab individu; 4) penggunaan keterampilan-keterampilan 
interpersonal dan usaha yang intens untuk meningkatkan efektivitas kelompok (Arends, 2008; Lie, 2004). Menurut Zakaria dan Iksan (2007), melalui pembelajaran kooperatif mahasiswa diharapkan dapat saling bekerjasama dalam memahami dan menyelesaikan soal-soal yang diberikan dan hal semacam ini yang tidak ditemukan dalam pembelajaran tradisional. Lebih lanjut dijelaskan bahwa melalui pembelajaran kooperatif, dosen diharapkan dapat mengelola kelas dengan lebih efektif sehingga kualitas pendidikan yang baik dapat tercapai (Chiu, 2004; Kolawole, 2008; Zakaria dan Iksan, 2007). Metode pembelajaran kooperatif juga dianggap efektif untuk meningkatkan motivasi belajar dan prestasi belajar siswa (Croce, 2007; Kolawole, 2008; Slavin, 2008; Zakaria dan Iksan, 2007). Menurut Ghaith dan ElMalak (2004), pembelajaran kooperatif dapat mendorong siswa untuk berfikir kritis dan meningkatkan kreativitas.

Beberapa metode kooperatif dapat diterapkan dalam pembelajaran bahasa asing, khususnya Bahasa Jepang. Melalui tulisan ini akan dilihat pengaruh penerapan metode kooperatif tipe paired story-telling, rotating trio exchange, presentation, dan metode konvensional dengan dosen sebagai pemberi materi utama dalam mata kuliah Membaca III.

Paired story-telling merupakan metode interaktif antar siswa, pengajar, dan bahan pelajaran, dengan menggabungkan kegiatan membaca, menulis, mendengarkan, dan berbicara (Lie, 2008). Inti dari pembelajaran ini adalah mahasiswa berperan aktif membangun pemikiran yang dimiliki dan bertukar pikiran bersama teman kelompoknya dan dosen. Rotating trio exchange merupakan metode belajar dengan kelompok-kelompok kecil berjumlah tiga orang dalam satu kelompok. Selanjutnya, setiap kelompok diberikan pertanyaan terkait bacaan untuk didiskusikan, kemudian masingmasing anggota diberikan nomor dan berpindah kelompok untuk berdiskusi dengan teman dari kelompok lain. Metode presentasi memadukan kemampuan pemahaman dan berbicara mahasiswa agar mampu menyampaikan hasil pembacaannya di depan kelas dan menanggapi pertanyaan dari teman. Melalui penerapan beberapa metode tersebut dapat dilihat tingkat pemahaman mahasiswa melalui nilai akhir yang didapat. 
Penerapan Metode Kooperatif Dalam Mata Kuliah Membaca

Metode kooperatif diterapkan pada mahasiswa tahun kedua (Angkatan 2014) dalam mata kuliah Membaca III di Program Studi DIII Bahasa Jepang Sekolah Vokasi UGM sebagai subjek penelitian. Subjek penelitian dibagi dalam dua kelas, A dan B. Metode yang digunakan adalah kooperatif tipe paired story telling. Di samping itu, dalam perkuliahan digunakan pula metode teacher centered learning dan reading aloud. Alat ukur yang digunakan dalam penelitian ini berupa teks bacaan berbahasa Jepang, disertai dengan soalsoal terkait bacaan. Teks berbahasa Jepang dipersiapkan bervariasi dengan tingkat kesulitan yang sama

Ada dua metode yang digunakan dalam penelitian ini, yaitu metode observasi dan metode tes. Metode observasi digunakan untuk mengumpulkan data dengan jalan mengamati langsung terhadap obyek yang diteliti. Metode tes digunakan untuk mengukur tingkat pemahaman mahasiswa terhadap materi bacaan. Tes diberikan untuk mendapatkan data kuantitatif, yaitu data nilai hasil pemahaman dan mendengar cerita secara deskriptif.

Mahasiswa dikatakan tuntas dalam pembelajaran ini apabila bisa mencapai nilai minimal 55, yang dikonversi ke dalam nilai huruf $C$. Kriteria kelulusan yang sebenarnya adalah D, tetapi karena nilai D dianggap kurang, maka sebagai indikator dalam penelitian ini diambil nilai C, yaitu 55 sebagai indikator tuntas (nilai yang dianggap cukup). Sebagai tolok ukur keberhasilan dalam pembelajaran membaca dengan menggunakan metode cooperative learning kriteria keberhasilan adalah $75 \%$ dari seluruh mahasiswa.

Beberapa tahapan dilakukan untuk melihat pengaruh penerapan metode pembelajaran dalam mata kuliah Membaca. Penelitian dilakukan menggunakan model spiral, dengan siklus yang berisi beberapa tahapan kerja. Tahapan-tahapan tersebut adalah perencanaan, tindakan, observasi, dan refleksi. Berikut ini dijelaskan tahapan kerja penelitian yang dilakukan.

1. Planning (perencanaan)

Perencanaan dilakukan dengan mempersiapkan alur dan bahan bacaan. Tahap I merupakan pre-test dengan model pembelajaran teacher centered 
learning. Persiapan yang dilakukan oleh peneliti pada tahap I dan II antara lain:

a. Membuat rencana pelaksanaan pembelajaran.

b. Menyiapkan bahan bacaan dan soal-soal.

c. Menyiapkan alat yang akan digunakan siswa untuk melakukan diskusi

2. Action (tindakan).

Tindakan yang dilakukan pada tahap I adalah:

a. Dosen menyampaikan tujuan dan materi pembelajaran.

b. Dosen menjelaskan isi bacaan, mahasiswa menyimak bacaan, dan menjawab pertanyaan.

c. Dosen memberikan soal dan memandu pembahasan soal-soal tersebut.

Tindakan yang dilakukan pada tahap II adalah:

a. Dosen menyampaikan tujuan materi pembelajaran, dan aturan pembelajaran

b. Dosen membagi mahasiswa ke dalam kelompok untuk melakukan diskusi.

c. Dosen memberikan soal-soal terkait bacaan d. Dosen memberikan penguatan dan umpan balik positif.

e. Dosen melakukan evaluasi dan penugasan, serta membuat simpulan pembelajaran dengan bersama mahasiswa.

3. Reflektion (refleksi)

Cara mengukur keberhasilan siswa baik dari segi kuantitatif maupun kualitatif dapat dilakukan dengan analisis. Setelah proses analisis, kemudian dapat disampaikan refleksi terhadap hasil analisis. Dengan demikian dapat disampaikan refleksi sebagai berikut:

a. Peningkatan kemampuan mahasiswa dalam menerima materi pembelajaran.

b. Dengan menggunakan metode kooperatif mahasiswa menjadi lebih mudah memahami materi dan bisa mengerjakan soal-soal tentang materi bacaan yang telah dipelajari.

Penelitian ini menggunakan desain pre-test and post-test group, dengan menggunakan dua kelompok subjek, yaitu kelompok eksperimen dan kelompok kontrol. Kelompok eksperimen adalah kelompok yang diberikan perlakuan (treatment) dan kelompok kontrol adalah kelompok yang tidak 
diberikan perlakuan. Untuk mengetahui efektivitas penggunaan metode, dilakukan analisis data dengan menggunakan metode komparatif. Pada tahap pertama dilakukan pengukuran untuk mengetahui kemampuan awal masing-masing kelompok (pre-test), kemudian salah satu kelompok yaitu kelompok eksperimen diberi perlakuan (treatment), seperti dalam desain eksperimen berikut.

\begin{tabular}{|c|c|c|c|}
\hline $\begin{array}{c}\text { Kelompok } \\
\text { kelas }\end{array}$ & Pre-test & $\begin{array}{c}\text { Perlakuan } \\
\text { (treatment) }\end{array}$ & Post-test \\
\hline $\mathrm{E}$ & $\mathrm{T} 1$ & $\mathrm{X}$ & $\mathrm{T} 2$ \\
\hline $\mathrm{K}$ & $\mathrm{T} 3$ & - & $\mathrm{T} 4$ \\
\hline
\end{tabular}

Tabel 1. Desain Eksperimen

Keterangan tabel:

$\mathrm{E}$ : kelas eksperimen

$\mathrm{K}$ : kelas kontrol

$\mathrm{X}$ : perlakuan (treatment)

$\mathrm{T} 1$ : pre-test kemampuan membaca kelas eksperimen

T2 : post-test kemampuan membaca kelas eksperimen

T3 : pre-test kemampuan membaca kelas kontrol

T4 : post-test kemampuan membaca kelas control

Pada tahap akhir dilakukan tes kemampuan pemahaman bacaan (posttest) untuk kedua kelompok. Dari

\footnotetext{
${ }^{3}$ Setyaningsih, Wahyu Handayani. 2016.

Penerapan Metode Pembelajaran Kooperatif Tipe
}

penelitian ${ }^{3}$ yang dilakukan, diketahui bahwa dengan tindakan (treatment) yang dilakukan pada kelas eksperimen berpengaruh terhadap hasil pembelajaran (pemahaman) mahasiswa terhadap teks bacaan dengan nilai ratarata semula 59,1 menjadi 75 . Hal ini menunjukkan adanya peningkatan kemampuan mahasiswa dalam membaca dan memahami teks bacaan dengan prosentase peningkatan sebanyak $25 \%$. Terdapat perbedaan antara kelas dengan treatment model pembelajaran kooperatif dan dengan metode konvensional. Pada kelas eksperimen, jumlah mahasiswa dengan nilai di atas 55 meningkat sebanyak 25\%, sedangkan pada kelas kontrol jumlah mahasiswa dengan nilai di atas 55 hanya meningkat sebanyak $17 \%$ dari nilai pre-test. Hasil analiss statistik deskriptif kelas kontrol dan eksperimen disajikan dalam tabel berikut.

\begin{tabular}{|l|c|c|}
\hline Data statistic & Kelas eksperimen & Kelas kontrol \\
\hline Mean & 59,1 & 71,9 \\
\hline Modus & 70 & 75 \\
\hline Median & 60,5 & 75 \\
\hline Standar deviasi & 20,54 & 13,7 \\
\hline
\end{tabular}

Tabel 2. Deskripsi hasil penelitian pre-test

Paired Story-Telling Dalam Mata Kuliah Membaca Pada Program Studi Bahasa Jepang. Laporan Penelitian Sekolah Vokasi UGM. 
Dari tabel di atas diketahui bahwa pada kelas eksperimen besar Mean $<$ Median $<$ Modus, dengan standar deviasi sebesar 20,54, sedangkan pada kelas kontrol diketahui bahwa Mean $<$ Median=Modus, dengan standar deviasi sebesar 13,7. Hasil pre-test menunjukkan bahwa pada kelas eksperimen rata-rata nilai mahasiswa cenderung rendah. Kemudian dilakukan tindakan (treatment) pada kelas eksperimen. Data hasil post-test dianalisis sebagai berikut.

\begin{tabular}{|l|c|c|}
\hline Data statistic & Kelas eksperimen & Kelas kontrol \\
\hline Mean & 75 & 75,25 \\
\hline Modus & 80 & 80 \\
\hline Median & 80 & 80 \\
\hline Standar deviasi & 17,66 & 14,96 \\
\hline
\end{tabular}

Tabel 3. Deskripsi hasil penelitian post-test

Dari tabel di atas diketahui bahwa hasil post-test pada kelas eksperimen Mean $<$ Median=Modus, dengan standar deviasi sebesar 17,66, sedangkan pada kelas kontrol diketahui bahwa Mean $<$ Median=Modus, dengan standar deviasi sebesar 14,96. Dari kedua tabel di atas diketahui bahwa dengan tindakan (treatment) yang dilakukan pada kelas eksperimen berpengaruh terhadap hasil pembelajaran (pemahaman) mahasiswa terhadap teks bacaan dengan nilai rata- rata semula 59,1 menjadi 75 . Hal ini menunjukkan adanya peningkatan kemampuan mahasiswa dalam membaca dan memahami teks bacaan dengan prosentase peningkatan sebanyak $25 \%$.

Melalui uji hipotesis yang dilakukan dapat diketahui bahwa terdapat perbedaan antara kelas dengan treatment model pembelajaran kooperatif tipe paired story-telling dengan kelas control melalui metode konvensional. Pada kelas eksperimen, jumlah mahasiswa dengan nilai di atas 55 meningkat sebanyak 25\%, sedangkan pada kelas kontrol jumlah mahasiswa dengan nilai di atas 55 hanya meningkat sebanyak 17\%. Meskipun tidak menunjukkan angka yang signifikan, tetapi berdasarkan hasil analisis, dapat diketahui bahwa model pembelajaran kooperatif tipe paired story-telling memberikan pengaruh yang lebih baik dibandingkan dengan model pembelajaran konvensional.

Untuk melihat perbedaan pengaruh penerapan kedua metode, dilakukan uji komparatif. Setelah dilakukan uji komparatif, diperoleh hasil bahwa pemahaman mahasiswa terhadap isi bacaan meningkat. Jika dilihat dari angka yang diperoleh, peningkatan 
tersebut mencapai $25 \%$ pada kelas eksperimen. Berdasarkan observasi, hal ini disebabkan oleh beberapa faktor, yaitu:

1) Setiap mahasiswa terlibat aktif dalam proses pemahaman bacaan;

2) Setiap mahasiswa memiliki kesempatan berinteraksi dengan mahasiswa lain sehingga memungkinkan adanya pertukaran informasi;

3) Setiap mahasiswa terpacu untuk lebih mengembangkan diri.

Pembelajaran kooperatif tipe paired story-telling mengacu pada paham konstruktivisme, yang berpandangan bahwa pengetahuan merupakan hasil konstruksi kognitif melalui suatu aktivitas sehingga mahasiswa dapat mengkonstruksi pengetahuannya sendiri, serta berkembang melalui interaksi dalam kelompok diskusi. Hal ini berbeda dengan model pembelajaran konvensional (teacher centered learning) yang lebih mengacu pada paham behavioristik. Peran pengajar menurut paham ini lebih dominan dalam pembelajaran sebagai pemberi stimulus sehingga mahasiswa cenderung pasif (Jauhar, 2011). Di samping metode paired story-telling, pada kelas Membaca dilakukan pula ujicoba dengan metode rotating trio exchange. Melalui hasil uji coba kedua, didapatkan hasil peningkatan nilai rata-rata mahasiswa dari 75 menjadi 77.

Pada mata kuliah Membaca III untuk mahasiswa angkatan 2015, diberikan treatment tambahan dengan metode presentasi bagi mahasiswa. Mahasiswa membentuk kelompok yang terdiri atas dua orang dan diminta membaca bacaan secara mandiri. Selanjutnya, kelompok mahasiswa diminta untuk mempresentasikan hasil pembacaannya di depan kelas. Usai presentasi, mahasiswa lain diminta memberikan tanggapan atau pertanyaan terhadap presenter. Melalui metode presentasi ini, diharapkan dapat melatih kemandirian mahasiswa dan keberanian dalam berkomunikasi. Dalam tabel berikut ini disajikan perbandingan nilai rata-rata hasil pembacaan dan pemahaman mahasiswa dari dua angkatan terhadap teks bacaan berbahasa Jepang menggunakan beberapa metode pembelajaran. 


\begin{tabular}{|l|c|c|}
\hline \multirow{2}{*}{\multicolumn{1}{|c|}{ Metode }} & \multicolumn{2}{|c|}{$\begin{array}{c}\text { Rerata nilai mahasiswa } \\
\text { di kls eksperimen (di } \\
\text { atas 55) }\end{array}$} \\
\cline { 2 - 3 } & 2014 & 2015 \\
\hline teacher centered & 59.1 & 65.9 \\
\hline paired story telling & 75 & 80 \\
\hline rotating trio exchange & 77 & 80.3 \\
\hline Presentasi & - & 78.3 \\
\hline
\end{tabular}

Tabel 4. Perbandingan nilai rata-rata mahasiswa pada kelas eksperimen

Dalam tabel di atas diketahui bahwa dengan beberapa treatment yang dilakukan menghasilkan pengaruh yang berbeda-beda terhadap tingkat pemahaman mahasiswa. Tingkat keterlibatan mahasiswa dalam proses pembelajaran dinilai menjadi faktor penting dalam meningkatnya hasil belajar. Hal ini terlihat dari nilai rata-rata yang meningkat dibandingkan dengan penggunaan metode teacher centered learning ketika dosen menjadi pusat pembelajaran. Pada angkatan 2015, dengan metode teacher centered learning nilai rata-rata mahasiswa sebesar 65.9. Setelah penerapan metode tersebut, mahasiswa kemudian diberikan treatment dengan metode paired story telling dan nilai rata-rata yang diperoleh meningkat menjadi 80 . Terjadi peningkatan nilai rata-rata sebesar $18 \%$. Peningkatan lebih besar terjadi setelah menggunakan metode rotating exchange.
Nilai rata-rata mahasiswa menjadi 80.3.

Melalui observasi yang dilakukan selama proses pembelajaran, diketahui terdapat beberapa factor yang memengaruhi peningkatan nilai tersebut, yaitu (1) semua mahasiswa dituntut untuk memahami bacaan agar dapat menjawab pertanyaan secara personal sehingga membuat mahasiswa menjadi lebih aktif dalam mencari tahu dan memahami; (2) terjadi proses diskusi yang lebih aktif dalam kelompok-kelompok kecil tiga orang sehingga mahasiswa yang biasanya pasif menjadi lebih berani bertanya dalam kelompok kecil; (3) melalui rotating exchange dengan teman dari kelompok lain, terjadi proses saling melengkapi pengetahuan sehingga pemahaman terhadap suatu bacaan menjadi lebih lengkap; (4) dosen menjadi fasilitator dengan berkeliling ke setiap kelompok sehingga memungkinkan untuk dapat memberikan masukan yang berbeda sesuai kondisi dan tingkat pemahaman mahasiswa.

Akan tetapi, di samping memiliki kelebihan metode paired story telling dan rotating trio exchange juga memiliki kelemahan, yaitu memerlukan waktu perkuliahan yang lebih lama dibandingkan dengan metode 
konvensional. Untuk mengatur waktu agar dapat disesuaikan dengan alokasi jadwal, ada dua cara yang bisa dilakukan dosen, yaitu (1) memberikan teks bacaan sebelum perkuliahan, atau memberikan teks bacaan yang dapat diperkirakan selesai dibaca dan dipahami dalam waktu maksimal 15 menit. Dalam penelitian ini digunakan pilihan kedua dengan kosakata yang sudah diberikan sebelumnya sehingga pada saat perkuliahan mahasiswa dapat menggunakan waktu selama 15 untuk proses memahami bacaan. Selanjutnya, 60 menit digunakan untuk rotating exchange dan diskusi singkat dalam kelompok kecil. Setelah tiga kali proses rotasi, mahasiswa diberikan pertanyaan tentang bacaan dan diberikan waktu maksimal 15 menit untuk menjawab. Sisa waktu 10 menit digunakan untuk refleksi. Melalui metode tersebut, seluruh mahasiswa dapat terlibat dalam proses diskusi sehingga memungkinkan untuk mendapatkan pemahaman yang lebih lengkap.

Treatment berikutnya yang
diberikan yaitu dengan metode
presentasi. Dalam metode presentasi ini,
mahasiswa diberikan kesempatan yang
lebih besar untuk memilih bahan bacaan

dan memahaminya secara mandiri. Kelompok terdiri atas dua orang. Setelah melewati proses pembacaan, pada pertemuan berikutnya mahasiswa diminta mempersiapkan presentasi. Mahasiswa menceritakan kembali hasil pembacaannya dalam Bahasa Jepang. Usai presentasi, mahasiswa yang lain diminta mengajukan pertanyaan atau tanggapan kepada kelompok presenter. Pertanyaan dapat diajukan dalam Bahasa Jepang maupun Bahasa Indonesia. Melalui metode ini, diperoleh nilai ratarata mahasiswa sebesar 78.3 .

Penggunaan metode presentasi dapat melatih skill komunikasi mahasiswa. Mahasiswa dituntut untuk dapat mempersiapkan materi presentasi yang menarik dan dituntut untuk mampu berbicara di depan kelas dalam Bahasa Jepang. Dengan metode ini, mahasiswa menjadi lebih berani berbicara guna melatih skill komunikasi di depan umum dan kepercayaan dirinya. Di samping kelebihan tersebut, terdapat beberapa kelemahan dalam metode presentasi, yaitu (1) tidak semua mahasiswa aktif dalam diskusi. Kecenderungan yang terjadi, mahasiswa yang aktif akan mengajukan pertanyaan lebih sering, sedangkan mahasiswa yang merasa tidak 
mampu akan cenderung pasif dan tidak berani bertanya sehingga diskusi lebih didominasi beberapa kelompok mahasiswa saja; (2) proses pembelajaran memakan waktu yang lebih lama sehingga presentasi harus dibagi ke dalam beberapa kali tatap muka di kelas.

Dalam pembelajaran kooperatif, dosen berperan sebagai fasilitator, mediator, dan motivator, sedangkan mahasiswa secara aktif mencari dan menyusun pengetahuan baru melalui kegiatan membaca, mencari cara baca setiap kata dalam kanji dengan kamus kanji, mencari arti kata di kamus, memahami ungkapan, serta berinteraksi dalam kelompok kooperatif dan diskusi kelas. Kegiatan mandiri ini sangat mempengaruhi proses pemahaman mahasiswa terhadap suatu teks. Dengan metode ini, mahasiswa pasif mejadi lebih aktif mencari karena adanya target. Dalam pembelajaran ini, dosen hanya memberikan penjelasan seperlunya, memandu diskusi mahasiswa, dan memberikan feedback dalam proses diskusi tersebut. Dari penerapan beberapa metode pembelajaran tersebut dapat diketahui bahwa variasi metode

\footnotetext{
${ }^{4}$ Kundharu Saddhono dan St. Y. Slamet,
} Meningkatkan Keterampilan Berbahasa memberikan pengaruh positif bagi mahasiswa.

\section{Reading Aloud dan Menghafal}

Reading aloud atau membaca bersuara merupakan salah satu metode guna melatih kemampuan membaca mahasiswa. Melalui metode ini, mahasiswa tidak hanya dilihat kemampuan membaca kalimat dengan huruf Jepang, tetapi juga dapat dilihat pengucapan dan intonasi bacaan. Membaca bersuara atau nyaring adalah kegiatan membaca dengan menyuarakan tulisan yang dibacanya dengan ucapan dan intonasi yang tepat, agar pendengar dan pembaca dapat menangkap informasi yang disampaikan oleh penulis ${ }^{4}$. Metode ini bermanfaat untuk membiasakan mahasiswa dengan pengucapan Bahasa Jepang yang tepat.

Di samping membaca bersuara, dalam pembelajaran Bahasa Jepang dikenal pula metode anshou (暗唱), yaitu menyuarakan bacaan yang telah dihafal. Dalam metode ini, mahasiswa sebelumnya telah diberikan bahan bacaaan untuk dibaca dan dipelajari di rumah. Mahasiswa diminta latihan membaca secara mandiri, dan

Indonesia, (Bandung: Karya Putra Darwati, 2012), h. 83. 
selanjutnya diminta untuk berdiri dan mengucapkan bacaan yang telah dipelajari di rumah.

Dalam kelas Membaca yang menjadi objek penelitian ini, dipadukan beberapa metode di atas dengan metode membaca bersuara dan menghafal. Reading aloud dilakukan di awal perkuliahan dan biasanya tidak berupa keseluruhan bacaan. Untuk proses ini dialokasikan waktu 5-10 menit dan hanya diberikan secara bergilir kepada beberapa mahasiswa. Metode reading aloud diberikan sebagai warming up sebelum memulai kegiatan pembelajaran di kelas. Metode ini dinilai merupakan salah satu cara yang baik untuk membiasakan mahasiswa dengan pengucapan dan intonasi bahasa asing, dalam hal ini Bahasa Jepang. Meskipun pada awalnya masih berupa hafalan, tetapi dengan metode ini mahasiswa menjadi terlatih untuk berbicara dengan pengucapan dan intonasi yang tepat. Penelitian mengenai penerapan metode reading aloud dalam pembelajaran bahasa asing dan pengaruhnya terhadap mahasiswa dilakukan oleh Sueyon Seo yang dimuat dalam GSTF International Journal on Education (JEd) Vol.2 No.1, terbit bulan Juni 2014. Kesimpulan atas hasil penelitiannya dapat dilihat dalam kutipan berikut.

Although many other factors such as class performance and activities, individual differences, students' personalities and their motivation in learning languages may impact the study results, it is reasonably clear that reading aloud can be a good method for students learning foreign languages in nonimmersion setting.

In conclusion, even though their early stage speaking level was not the same, reading aloud resulted in progress in students' speaking level and their usage of grammar. By reading aloud repeatedly, students were able to get used to the unique sounds of Japanese pronunciation and produce more natural sentences. This also boosted their confidence in speaking Japanese. Considering that the practice had been done only for 5 minutes daily in class as a warm-up activity, the positive effect is particularly promising.

Melalui penelitian tersebut, Seo menemukan bahwa metode reading aloud yang diterapkan memberikan pengaruh positif terhadap kemampuan berbahasa Jepang mahasiswa. Metode reading aloud melatih mahasiswa untuk mengucapkan kosakata dan membaca kalimat dengan pengucapan yang benar. Metode ini juga dapat meningkatkan kepercayaan diri mahasiswa dalam berbicara menggunakan Bahasa Jepang. 
Metode reading aloud dapat diterapkan sebagai warm-up activity selama 5-10 menit dalam kelas Membaca.

\section{Kesimpulan}

Berdasarkan penelitian dapat diketahui bahwa penggunaan metode pembelajaran yang bervariasi memberikan pengaruh positif terhadap hasil belajar mahasiswa. Hal ini dapat dilihat melalui peningkatan nilai rata-rata mahasiswa dalam mata kuliah Membaca. Dari studi komparasi diketahui jumlah mahasiswa dengan nilai di bawah angka kelulusan dibandingkan dengan kelas konvensional. Ditemukan adanya perbedaan dalam hasil akhir antara mahasiswa di kelas kontrol dengan kelas eksperimen. Hal ini terlihat dari rata-rata hasil post-test pada kelas eksperimen yang meningkat dibandingkan dengan hasil pada kelas kontrol.

Ada beberapa manfaat yang bisa diperoleh melalui penerapan beberapa metode pembelajaran ini, yaitu: (1) mahasiswa menjadi lebih aktif mencari kosakata baru serta berusaha mandiri dalam memahami kalimat dan ungkapan yang terdapat dalam bacaan berbahasa Jepang; (2) mahasiswa memiliki kesempatan lebih banyak untuk berpikir kreatif dalam mengembangkan Jurnal Lingua Aplicata Volume 1, Nomor 1 September 2017 pengetahuannya; (3) menunjang kemampuan berinteraksi dan bersosialisasi mahasiswa; (4) melatih kemampuan berkomunikasi di depan umum (kelas) bagi mahasiswa sehingga lebih berani dan percaya diri dalam berbicara, khususnya dalam Bahasa Jepang. Di samping beberapa metode di atas, penggunaan metode reading aloud sebagai salah satu bentuk warming up activity di menit-menit awal perkuliahan dinilai memiliki pengaruh positif dalam meningkatkan kemampuan berbahasa Jepang mahasiswa.

\section{Daftar Pustaka}

Arends, R.I. 2008. Learning to Teach: Belajar untuk Mengajar. Yogyakarta: Pustaka Pelajar.

Arikunto, S. 2007. Dasar-dasar Evaluasi Pendidikan. Jakarta: Bumi Aksara.

Azwar, S. 2006. Reliabilitas dan Validitas. Yogyakarta: Pustaka Pelajar.

Chiu, M.M. 2004. Adapting Teacher Interventions to Student Needs During Cooperative Learning: How to Improve Student Problem Solving and Time ontask. American Educational Research Journal, 41, 365-399.

Croce, L. 2007. The Effect of Cooperative Learning on Elementary School Student's Academic Achievement and Pro-Social Behavior. Cortland: Degree Master of Science in Teaching.

Djafri, Fatmawati. 2012. Tingkat Kecemasan Bahasa Asing dan Penerapan Pembelajaran Kolaboratif di Program Studi Bahasa Jepang Sekolah Vokasi Universitas Gadjah Mada. Yogyakarta: Laporan Akhir Penelitian Sekolah Vokasi UGM. 
Hapsari, Elisabeth Widyaning. 2010. Penggunaan Metode pembelajaran kooperatif STAD untuk meningkatkan prestasi Bahasa Indonesia pada siswa SMP. Yogyakarta: Tesis UGM.

Helmi, Ryzka Adhiyani. 2011. Pengaruh Metode Pembelajaran Kooperatif Jigsaw Terhadap Prestasi Belajar Biologi pada Siswa SMA. Yogyakarta: Tesis UGM.

Jauhar, Muhammad. 2011. Implementasi Paikem dari Behavioristik Sampai Konstruktivistik. Jakarta: Prestasi Pustakarya.

Kolawole, E.B. 2008. Effect of Competitive and Cooperative Learning Strategies on Academic Performance of Nigerian Students in Mathematics. Educational Research and Review Academic Journal, 3 (1), 033-037.

Kundharu Saddhono dan St. Y. Slamet. 2012. Meningkatkan Keterampilan Berbahasa Indonesia, Bandung: Karya Putra Darwati.

Mansur, H.R. 2015. Menciptakan Pembelajaran Efektif Melalui Apersepsi. Widyaiswara LPMP Provinsi Sulawesi Selatan E-
Buletin, Edisi Februari 2015, ISSN. 23553189.

Setyaningsih, Wahyu Handayani. 2016. Penerapan Metode Pembelajaran Kooperatif Tipe Paired Story-Telling Dalam Mata Kuliah Membaca Pada Program Studi Bahasa Jepang. Laporan Penelitian Sekolah Vokasi UGM.

Seo, Sueyon. 2014. Does Reading Aloud Improve Foreign Language Learner's Speaking Ability? Dalam GSTF International Journal on Education (JEd) Vol.2 No.1, Edisi Juni 2014.

Winkel, W.S. 1996. Psikologi Pengajaran. Jakarta: Gramedia.

Zakaria, E. dan Iksan Z. 2007. Promoting Cooperative in Science and Mathematics Education: A Malaysian Perspective. Eurasia Journal of Mathematics, Science, and Technology Education, 3 (1), 35-39.

\section{Daftar laman:}

https://www.nsa.gov/news-

features/declassified-

documents/cryptologic-

spectrum/assets/files/foreign language.pdf.

(diakses 5 Agustus 2017, pukul 00.53) 